\title{
DISCUSSION
}

\section{ENGLISH LANGUAGE TEACHERS' PRACTICES OF DEVELOPING DISCOURSE COMPETENCE THROUGH SPEAKING SKILLS FOR GRADE 10 STUDENTS: A CASE STUDY}

\author{
Vu Hai Ha, Nguyen Nha Uyen* \\ Faculty of English Language Teacher Education, \\ VNU University of Languages and International Studies, Pham Van Dong, Cau Giay, Hanoi, Vietnam
}

Received 2 February 2021

Revised 15 April 2021; Accepted 23 July 2021

\begin{abstract}
Being one of the compulsory foreign languages in Vietnam and recently regarded as one of the requirements for higher education enlistment, English has received growing attention from Vietnam high school students (Nguyen, 2021). In Circular 32 (2018), the Vietnam Ministry of Education and Training [MOET] officially recognised communicative competence as the primary outcome of the English National Program of which Discourse Competence (DC) is a crucial component (MOET, 2018). Although the program aims to achieve the outcome with more emphasis on listening and speaking skills, Vietnamese high school students remain to struggle to form extended spoken discourse (Le, 2011). With the view to gaining insights into the actual state of cultivating DC through speaking skills in students, the study investigates four Grade 10 teachers with varied backgrounds and teaching styles in a private school awarded twice by the MOET for educational reforms and their attempts to integrate CLT in the English language teaching curriculum. After conducting the interviews and classroom observation, the findings imply that teachers devised a combination of approaches that had implicit impacts on different aspects of DC-based on students' English proficiency while preserving their teaching philosophies. Such innovativeness could suggest a rudimentary framework for teaching and teacher training programs regarding fostering DC in speaking for EFL students.
\end{abstract}

Keywords: English language teachers, discourse competence, speaking skills, perceptions, practices, grade 10 students, Hanoi

\section{Introduction}

With the emergence of globalisation, the demand for a measure to support crosscountry communications grows. Consequently, people start to focus on language applications rather than language subject learning (Castro et al., 2004). The
English language in Vietnam has been given more credibility recently with the observable surge in the number of universities that include international language certification into one of its criteria for enlistment (Ngoc, 2021). Therefore, students need to make a detailed plan for their English learning since grade 10th to reach level B1 according to

\footnotetext{
* Corresponding author.

Email address: nhauyen6299@gmail.com

https://doi.org/10.25073/2525-2445/vnufs.4754
} 
CEFR after graduation from high school (Vietnam Ministry of Education and Training, 2018) and increase their chances of getting into a qualified university (Ngoc, 2021). To catch up with the status quo, the Ministry of Education and Training [MOET] has released Circular 32 in 2018, aiming to renovate the National English Program that gave official recognition of CLT with emphasis on listening and speaking skills with communicative competence as the outcome (MOET, 2018). Although speaking is recognised as a critical skill in language learning (Egan, 1999), students are accustomed to a grammar-based approach. Quite predictably, they found producing an extended speech an arduous task (Le, 2011; Nguyen, 2021).

Dating back to the last few decades, numerous efforts have been put into delineating and constructing a relevant framework to foster and assess communicative competence, the ultimate outcome of language learning (Canale \& Swain, 1980; Celce-Murcia et al., 1995; Pham, 2007). Among components of communicative competence, discourse competence (DC), the ability to produce extended text and speech (Pennycook, 1994), is crucial in achieving communicative competence and interacting efficiently in a cross-cultural environment (Castro et al., 2004). Despite the attempts to lay the theoretical groundwork for actual language teaching practices, investigations into applications and methods to cultivate communicative competence in students are limited, especially when it involves the techniques needed to foster a specific component of communicative competence. Regarding DC, past studies only focused on writing and reading skills (Mauranen, 1996; Do et al., 2018). Hence, to amend for the possible gap in the body of literature, this study aims at 1) the Grade 10 EFL teachers, who are at the frontline to be in charge of students' learning while concurrently facing numerous challenges, such as being inexperienced and the negative washback from the high-impact exams (Bui, 2006; Nguyen et al., 2017; Nguyen et al., 2020) 2) the issue of how to foster DC through speaking skills which is crucial to communicate in foreign languages (Egan, 1999). All in all, the research question of the study is:

"What are the teaching practices applied by English language teachers to foster the development of discourse competence through speaking skills for Grade 10 students?"

\section{Literature Review}

"Competence" was first coined by Chomsky (2014) that views language as existing independently from context. However, it is soon re-considered a dynamic process to use the language pragmatically (Savignon, 1983; Stern et al., 1983). Communicative competence can be generally understood as a set of knowledge and skills required to communicate (Canale \& Swain, 1980; Savignon, 1983). The goal of this concept is to put forward the fundamentals for effective communication (Celce-Murcia, 2008) and establish a foundation for CLT (Canale, 1983). According to Circular 32 (2018), communicative competence is "the ability to apply knowledge about language components like lexis, grammar, and phonology to fulfil communication activities in speaking, listening, writing, reading to meet personal or social demands" (MOET, 2018, p. 16). Communicative competence has been delineated through history, from only two components (linguistic and sociolinguistic) (Hymes, 1972) to five (Canale \& Swain, 1980; Canale, 1983; Celce-Murcia et al., 1995). The most updated model presented by Celce-Murcia et al. (1995) defines the five components as discourse competence, linguistic 
competence, actional competence, sociocultural competence, and strategic competence.

Discourse is broadly understood as any utterance larger than a sentence (Kinneavy, 1971; McCarthy, 1991), while competence, concerning discourse, is a dynamic process in which the realisation is the speaker's performance in real-life situations (Savignon, 1983). Therefore, discourse competence is the ability to arrange words, phrases, sentences, and other language structures into a well-connected and comprehensible text (Canale, 1983, 1984; Celce-Murcia, 2008). According to Table 1
Canale (1983), Celce-Murcia et al. (1995), four main sectors constitute discourse competence: cohesion, deixis, coherence, generic structure, and conversational structure. These sectors will serve as the framework for thematic data analysis in this paper for two reasons. First, this is the most detailed synthesis of what discourse competence includes. Second, each component is selected based on its role to constitute the manifestation of discourse and how it links with other competencies (such as linguistic, strategic, and socio-cultural). To be specific, the elaboration of each category is presented below.

Components of Discourse Competence (Celce-Murcia et al., 1995, p. 14)

\section{Cohesion}

- Reference (anaphora, cataphora)

- Substitution/ellipsis

- Conjunction

- Lexical chains (related to content schemata), parallel structure

\section{Deixis}

- Personal (pronouns)

- Spatial (here, there; this, that)

- Temporal (now, then; before, after)

- Discourse/textual (the following chart; the example above)

\section{Coherence}

- Thematisation and staging (theme-theme development)

- Management of old and new information

- Prepositional structures and their organisational sequences (temporal, spatial, cause-effect, condition-result, etc.)

- Temporal continuity/shift (sequence of tenses)

\section{Genre/Generic structures}

- Narrative, interview, service encounter, research report, sermon, etc. 
Conversational structures (inherent to the turn-taking system in conversation but may extend to a variety of oral genres)

- How to perform openings \& reopenings

- Topic establishment $\&$ change

- How to hold \& relinquish the floor

- How to interrupt

- How to collaborate \& backchannel

- How to do pre-closings and closings

- Adjacency pairs (related to actional competence), first and second pair parts (knowing preferred and dispreferred responses)

Practice is widely understood as collecting an individual's mindset, experience, skills, and behaviours (Larrivee, 2008). On top of that, the characteristic of practice is what the participants actively act out their consciousness in real situations, or in other words, what they do (Ellis, 2002; Grossman et al., 2009; Lampert, 2010). In this sense, teaching practice is when teachers carry out professional tasks based on their perceptions of a matter (Lampert, 2010). Practice entails techniques for facilitating the ability to connect language in alignment with the lesson objectives and some everyday activities to form different stages of classroom discourse like giving presentations, telling stories, etc. (Richard, 2005; Legutke, 2012). In this research, practices of fostering DC in students refer to how teachers monitor the classroom and set up activities that intentionally aim to facilitate a particular or a few aspects of DC.

Previous studies primarily focused on establishing the fundamentals of communicative competence models by eminent researchers, such as Halliday and Hasan (1989), Hymes (1972), Canale and Swain (1980), Celce-Murcia and Thurrell (1995), Bachman (1990), Savignon (1983), Brown (2000), and the like. In Asian countries and Vietnam, multiple attempts have been made to summarise the work of eminent experts to propagandise the benefits of CLT (Li, 1998; Maley, 1984; Liao, 2000; Do, 2009; Pham, 2017). Among different parts of communicative competence, discourse competence is prevalent in research looking into the EFL teaching of writing skills (Belmonte \& McCabe, 2004; Yang \& Sun, 2012), reading skills (Cziko, 1978; Mauranen, 1996; Ntuli \& Pretorius, 2005), and the integration of ICT to help developing discourse competence (Chun, 1994; Hussein et al., 2016). The findings implied that students' performance was improved with the advent of ICT. In Vietnam, Do (2018) conducted experimental research that showed students' writing skills have favourable progress when being taught discoursal knowledge.

Additionally, discourse competence is also underscored as the goal that language users should attain to communicate effectively in a multicultural environment (Castro et al., 2004; Ngo, 2012; Nguyen, 2016) with suggestions on diversifying the input of students in the class to enhance DC. The input should range from knowledge of the language, knowledge of the field/profession, to the world's knowledge (Do, 2009). In addition, the social-cultural understanding of the speaking context is deemed indispensable from discourse competence. Hence, the input relevant to this area is equally vital to cross-cultural interactions (Ngo, 2012). 
From what has been elaborated above, the research gaps are evident that could be filled by the study. First and foremost, most studies were theoretical. Hence, research that investigates applying such theories is radically on demand, which is one of this research's purposes. Second, the insufficient number of papers investigating the execution of the theoretical framework primarily revolved around writing and reading skills, with limited attention paid to speaking skills. While speaking is deemed to be crucial in communication, this absence should be more acknowledged. Finally, a certain hypothesis has been put forward regarding techniques to cultivate DC in students. Therefore, this study examines whether the participants, the EFL teachers, consider these suggestions and devise proper plans to support their students.

\section{Research Method}

The paper's primary approach is qualitative research design to examine the research problem that is socially sophisticated (Dörnyei, 2007). Because this study aimed to collect data to gain an indepth articulation to form plausible hypotheses about teacher's practices for further investigations, case study is a reasonable choice to achieve this end (Feagin et al., 1991).

The setting of the study is School A, the first campus of a private K-12 educational system with well-equipped teaching aids and technological devices. The English teaching of the school claims to foster students' ability to attain

\section{Table 2}

The Profiles of Four Investigated Cases

\begin{tabular}{lllll}
\hline Profile & Huong & Lan & Hoa & Lien \\
\hline Ages & 34 years old & 25 years old & 31 years old & 46 years old \\
\hline $\begin{array}{l}\text { Educational } \\
\text { backgrounds }\end{array}$ & $\begin{array}{l}\text { Bachelor }- \\
\text { Local university }\end{array}$ & $\begin{array}{l}\text { Bachelor }- \\
\text { Local university }\end{array}$ & $\begin{array}{l}\text { Master degree } \\
\text { awarded by }\end{array}$ & $\begin{array}{l}\text { Master degree } \\
\text { awarded by overseas }\end{array}$ \\
\hline
\end{tabular}

communicative competence based on the CEFR and the CES (Cambridge English Scale) with the help of various rating scales (the MBTI, the brain profile) to promote personalised learning. The English curriculum in school A follows a backward design, which means the course objectives are identified first, then EFL teachers could incorporate their unique teaching methods to help students communicate as global citizens (Wiggins \& McTighe, 2006). With the view to helping students function in a multicultural environment, DC is of key importance (Castro et al., 2004; Ngo, 2012; Nguyen, 2016). All in all, the aforementioned factors are conducive to the isolation of EFL teachers as an investigated subject with diverse approaches to developing DC in students, which is what this study attempts to discover.

Given the critical role of a proper strategy in the qualitative case study research (Gable, 1994), the study chose maximum variation sampling to render richer data and allow the researcher to compare among different participants to strengthen the validity of the findings. According to Postiglione et al. (2008), the teachers' practices have a close tie with their ages, educational background, years of experience, and relevant experiences. These contributing factors constitute the "knowledge, skills and attitudes towards learners" of the teachers, which could shape their practices (Borg, 2006, p. 7). Those are also the criteria for selecting participants. Their profiles are presented in the table below. The participants' identities are protected by using pseudonyms. 


\begin{tabular}{|c|c|c|c|c|}
\hline & & & $\begin{array}{l}\text { overseas } \\
\text { institution }\end{array}$ & institution \\
\hline $\begin{array}{l}\text { Years of } \\
\text { experiences }\end{array}$ & 11 & 3 & 8 & 16 \\
\hline $\begin{array}{l}\text { Relevant } \\
\text { experiences }\end{array}$ & $\begin{array}{l}\text { Specialised in } \\
\text { teaching false } \\
\text { beginner } \\
\text { students. }\end{array}$ & $\begin{array}{l}\text { Novice teacher. } \\
\text { Used to teach } \\
\text { English in public } \\
\text { school for } 2 \\
\text { years. }\end{array}$ & $\begin{array}{l}\text { Used to study } \\
\text { abroad for a } \\
\text { master's degree } \\
\text { in TESOL for } 1 \\
\text { year. }\end{array}$ & $\begin{array}{l}\text { Currently a senior } \\
\text { teacher and academic } \\
\text { manager. Used to be } \\
\text { the Head of the } \\
\text { English department in } \\
\text { her previous job. }\end{array}$ \\
\hline \multirow[t]{2}{*}{$\begin{array}{l}\text { Classroom } \\
\text { profile }\end{array}$} & \multirow{2}{*}{$\begin{array}{l}33 \text { students, } 12 \\
\text { girls and } 21 \\
\text { boys } \\
\text { Foundational } \\
\text { level, around } \\
\text { A2+ }\end{array}$} & $\begin{array}{l}34 \text { students, } 18 \\
\text { girls and } 16 \text { boys }\end{array}$ & $\begin{array}{l}31 \text { students, } 15 \\
\text { girls and } 18 \text { boys }\end{array}$ & $\begin{array}{l}32 \text { students, } 19 \text { boys } \\
\text { and } 13 \text { girls }\end{array}$ \\
\hline & & $\begin{array}{l}\text { Pre-intermediate } \\
\text { level, around B1- }\end{array}$ & $\begin{array}{l}\text { Upper- } \\
\text { intermediate } \\
\text { level, around B2- }\end{array}$ & $\begin{array}{l}\text { Advanced level, } \\
\text { around C1- }\end{array}$ \\
\hline
\end{tabular}

After sending the invitation letters and receiving approval from both the school principal and four EFL teachers, each

\section{Table 3}

Data Collection Procedure

\begin{tabular}{|c|c|}
\hline Name of the stages & Content of the stage \\
\hline $\begin{array}{l}\text { Pre-session interview } \\
(N=6)\end{array}$ & $\begin{array}{l}\text { Objectives of the lesson \& Rationale for each activity in the lesson in } \\
\text { terms of helping students to develop DC in students }\end{array}$ \\
\hline $\begin{array}{l}\text { Observation } \\
(N=6)\end{array}$ & Practices of developing discourse competence in class \\
\hline $\begin{array}{l}\text { Post-session interview } \\
(N=6)\end{array}$ & $\begin{array}{l}\text { Reflections on the lesson and the effectiveness of in-class practices to } \\
\text { develop DC in students }\end{array}$ \\
\hline
\end{tabular}

In the first observation session, the pre-lesson interview is supposed to collect the general methods that the participants prefer to use in their classrooms based on the components of discourse competence table by Celce-Murcia et al. (1995) that has been mentioned in the literature review. In the following sessions, the pre-observation interview is about the general information of the class (number of students, their levels and learning styles, lesson objectives and activities, the expected outcome of each activity). Accordingly, the post-observation interview reflects on the teacher's thoughts after the lesson. teacher had six observation sessions with a pre-session and post-session interview for each lesson.
Likewise, during the observation session, the data is collected using a side note and video recording to make data analysis convenient (Merrell \& William, 1994; Carroll et al., 2008; Collier et al., 2015). The observation side note is divided into two main parts: the first part collects information about the class's profile and overview of the lesson; the second part is the teaching practices that are intentionally contrived to help accelerate specific aspects of discourse competence according to the components of discourse competence by Celce-Murcia et al. (1995). 
Because the conceptual framework has clear pre-determined themes taken from Cele-Murcia et al. (1995) components of DC (including cohesion, deixis, coherence, generic structures, conversational structures), the thematic analysis appears to be convenient to gather findings from the data. The six-phase framework of thematic analysis designed by Braun and Clark (2006) is applied, including:

1) Familiarising with the data
2) Generating initial codes

3) Searching for themes

4) Reviewing themes

5) Defining and naming themes

6) Producing the report

The descriptive coding and In Vivo coding are applied to data taken from the interview; process coding to data from observation (Saldaña, 2009). The example of each type of coding is presented in the table below:

Table 4

Qualitative Coding Examples

\begin{tabular}{lll}
\hline Quote extract & Code - theme & Types of code \\
\hline $\begin{array}{l}\text { I saw that my students still struggled with } \\
\text { supporting their ideas because they could not } \\
\text { find the words to elaborate on their arguments. }\end{array}$ & $\begin{array}{l}\text { Insufficient lexical range - } \\
\text { lexical cohesion }\end{array}$ & $\begin{array}{l}\text { Descriptive } \\
\text { coding (Saldaña, } \\
\text { 2009) }\end{array}$ \\
\hline $\begin{array}{l}\text { A particular thing that I know when I'm working } \\
\text { with Vietnamese students is that the students } \\
\text { here are very scared to be wrong. }\end{array}$ & $\begin{array}{l}\text { Scared to be wrong - DC's } \\
\text { development's significance } \\
\text { \& feasibility }\end{array}$ & $\begin{array}{l}\text { In Vivo coding } \\
\text { (Saldaña, 2009) }\end{array}$ \\
$\begin{array}{l}\text { After each presentation session, the teacher } \\
\begin{array}{l}\text { always assigned a particular group of students } \\
\text { in the class to give feedback to the presenting } \\
\text { group. }\end{array}\end{array}$ & $\begin{array}{l}\text { Monitoring peer-feedback - } \\
\text { Generic structures }\end{array}$ & $\begin{array}{l}\text { Process coding } \\
\text { (Saldaña, 2009) }\end{array}$ \\
\hline
\end{tabular}

\section{Findings and Discussion}

\section{Huong - The constructor}

Most of the time, Huong specialised in facilitating false beginner students with foundational English proficiency, around A1 to A2, according to the CEFR. She was given the title "the constructor" because her core principle in teaching was to "help my students by starting small then gradually going up."

Huong noticed that her students, as false beginners, showed a significant lack of motivation. She exclaimed:

[Interview extract 1]

Many students only study because their parents want them to, do you agree? Many adults only want to study because they can get a higher salary instead of wanting to actually learn the language. Teaching them is like building blocks, and sometimes the task can be daunting as you do not want to work with people who already do not intend to study. (Huong)

Huong was careful and apprehensive when fostering cohesion. To gather the momentum for learning, Huong did not focus on deductively teaching students the discourse structures that helped them to be more cohesive in their speeches. She inductively exposed students to cohesive devices via input, such as reading materials, 
listening audios, and videos. The link between input and development of DC has been recognised by Do (2009) and Ngo (2012) when the input is the prerequisite for DC, especially grammatico-lexical cohesion.

Huong gave attention to both grammatical and lexical aspects of cohesion. In terms of grammar, she instructed students to practice the same structure with slight variation throughout a lesson. Regarding vocabulary, she extended the words with similar ones belonging to the same category and explained the connotations behind each word to widen students' lexical chains. The session was inductive rather than deductive, a more preferred instruction delivery approach in CLT (Nunan, 1987; Tan, 2005). It allows students to interact with the target content as a cognitive process (Piaget, 1976).

\section{[Observation extract 1]}

Huong: So what are your friends like?

Student A (who was reading the notes of student $B$ with three adjectives describing himself noted down): He is lazy, fat, and loyal.

\section{Huong: Really? B?}

Student B: Yes.

Huong: Alright, good job $A$ and $B$, but I don't think you should use that adjective. In English, there are words with similar meanings but have very different tones.

The class: yeah, true

Huong: You can, like, use chubby instead. Chubby is quite cute. But fat, no, if that was your girlfriend, you could be in great trouble.

\section{Class: (laugh)}

By giving prompts to students to produce their discourse first then navigating them to reflect on the connotations of their choices of language was one of the ways to leave a long-lasting impression of discourse formation on students (Long, 1981). As a result, they would be more mindful of picking up accurate expressions to use in specific contexts, which is believed to consolidate grammatico-lexical cohesion (Li, 2013).

Regarding coherence, Huong allowed students to constantly review and reflect on the thematic staging of their speech by noting down their ideas on the paper and using the notes for speaking. With the combination of task repetition (answering the question structure "what somebody is/are like") and pre-task planning (using side notes), the two most used scaffolding strategies, Huong could reduce the strain put on students if they had to impromptu. Notably, these scaffoldings also automatised some of the cognitive stages required for speaking so that students could focus more on the thematic structure of the speech (Cameron et al., 1996; Skehan, 1998; Segalowitz, 2010).

\section{[Observation extract 2]}

Huong: Next, please tell us what your parents like. C, can you tell me?

Student C: My mother is strict, violent, and hard-working.

Huong: What, your mom is violent?

Student C: Yes, when I do wrong, she will hit me. But I know she loves me in her own way.

Huong: That is typical of Asian moms. We have different levels of Asian moms, do you know? Like the slipper level, the broom level, the plate level.

(Some of the students started to giggle).

Student C: My mom uses hanger.

Huong: It's only a bit over slipper level. You are still lucky.

(C and other students laughed).

From the extract above, the conversation was genuine and casual because Huong demanded an authentic response from the students. Hence, no reading materials and dictionaries should be 
within grasp during practice sessions. As a result, students had to proactively organise their speech and partake in negotiation to adjust the discourse (Vygotsky, 1978).

Concerning generic structures, although the presentation was the only genre that the students were expected to perform, its familiarity spared students time to review the discourse formation of their spoken texts (Skehan, 1998; Segalowitz, 2010). Due to the tension Asian students experience when communicating in the target language (MacIntyre \& Gardner 1989; Li \& Lui, 2011), Huong refrained from the role of an instructor. She refused to correct students' mistakes or give feedback, although these might benefit them (Chaudron, 1988). Giving priority to reducing the affective barriers was a wise choice of Huong, particularly to beginners who might be affected more seriously (Cohen \& Norst, 1989).

\section{[Interview extract 2]}

I don't want students to feel that they are performing before a judging panel. I want to give them respect on par with an actual speaker. They will be more confident about themselves, and that in turn affects their output.

\section{Lan - The commander}

During her few years of teaching, Lan, a novice EFL teacher, taught preintermediate students around the A2-B1 level based on the CEFR. She owned the nickname "the commander" because of her teacher-front manner in class that even Lan acknowledged being the shortcoming herself. She partially blamed this on the ineffectiveness of professional training. This accusation is valid to some extent, as the lack of hands-on experience is one of the reasons why EFL teachers struggle to follow CLT and teacher-centred approach (Edwards, 1987; Pace, 1992; Nguyen et al., 2017; Nguyen \& Nguyen, 2020).

\section{[Interview extract 3]}

The professional training programs that we had regularly at school now only mentioned some general problems in teaching. I wish to have more content regarding how, in the most realistic and applicable ways, the teachers of national exam takers could effectively follow the communicative approach while remaining on the track to prepare for the exam...

The overall impression was slightly didactic regarding what strategies Lan had applied to foster students' discourse competence. Her lessons often followed a Presentation - Practice - Produce sequence, starting from reading and listening exercises to speaking practices. This is a natural sequence of language acquisition (Golkova \& Hubackova, 2014). However, Lan was aware that her students were reluctant to speak because they were accustomed to grammar-based teaching (Savaşçı, 2014). She provided deliberately detailed cue cards for the speaking sessions.

\section{[Observation extract 3]}

Lan: We have completed a reading passage about the traditions and customs of Russia and The UK. Now, we will do a speaking activity. We will learn how to compare things with what we learn from the passage. I will show on the slide the structures.

(On the slide): Compare: both $A$ and $B . .$. ; the things in common are...; similarly,...; $A$ is the same as $B$ in terms of...

Contrast: on the contrary; in contrast; $A$ is different from $B$ in terms of ...; on the other hand...; unlike $A, B$ is...

Lan: Alright, now who wants to volunteer?

One student: Teacher, but I speak very bad. 
Another student: Do you grade us for this?

Lan: Who can speak well will receive a bonus point. And who is called but refuses to speak will get the point deduced. I will show the structures, vocabulary and main ideas from the previous reading passage. You can look at it and speak.

Unlike Huong and other experienced EFL teachers, Lan spoon-fed students the structures, vocabulary and ideas to the point of over-scaffolding (Willis, 1996). It took away the freedom to produce and maintain a discourse independently to make it cohesive and coherent to the listeners (Piaget, 1976; Vygotsky, 1978).

Like Huong, Lan taught students the presentation format "because it was readymade in the textbook, so it is quite convenient". Lan relied extensively on feedback to guide students to present appropriately, even though she did not adhere to a pre-determined marking rubric. This might help to create an interactive lesson. However, the feedback was repetitive and redundant across different performances.

\section{[Observation extract 4]}

Lan: Okay, anyone wants to ask any question or comment. Remember this is compulsory. Group one, anyone wants to speak?

A student from group one: I think.. They speak very well. Especially students $X$ and $Y$. The slide is pretty, and the font is easy to read. But student $Z$ needs to speak more confidently.

Lan: I agree. The presentation is logical, the slide is nicely designed, they can use pictures and videos to illustrate their ideas. But I agree, Z needs to practice more at home. Maybe you should present in front of the mirror.

Most of the feedback had similar content. First, it mentioned the visual aid, then whether the speakers needed to "practice more" with no insightful suggestions or solutions. The absence of a well-defined marking rubric and proper peer-feedback training could be held accountable for this (Zhu, 1995; Berg, 1999).

\section{Hoa - The listener}

Hoa was an EFL teacher with considerable experience relating to intercultural communication. Her students were of around B1 to B2 level following the CEFR. Her students praised her for being an excellent listener because she paid close attention to what the students said during the lessons and could recall it with high accuracy in the subsequent speaking sessions. Even her students were amazed at her excellent memory.

Due to the time limitation, she organised speaking activities in the class following the think - pair - share sequence. Accordingly, students were guided to level up from just mechanically repeating what was learned, critically review the information, and then use it to create something of their own. Because the previous activity effectively scaffolded the subsequent ones, students had plenty of time to review the text's cohesive devices and coherent structures (Ellis, 2008; Wood et al., 1976).

The same as Huong and Lan, receptive input was an indispensable part of Hoa's classroom. Her speaking activities were tied with the content of the prior materials. A wide variety of input helped equip students with general knowledge, the foundation of DC development (Castro et al., 2004; Do, 2009; Ngo, 2012). She asked questions to help students figure out how the idea was arranged and supported in the text. Then, there was a follow-up speaking session where students had the chance to apply what they learned from the sample instantly into use. 


\author{
[Observation extract 5: Practice \\ instructions] \\ Talk about a job you would like to do. \\ Follow this template:
} person you are.

1. Describe yourself, what sort of

2. Say what you're good at.

3. Say what you're interested in.

4. Say what you hope you will be doing by the time you are 25 .

Example: I'm easy-going, patient, and creative. I'm good at working in a team. I'm interested in designing clothes so I'd really like to work in fashion. By the time I'm 25, I hope I will be working for a famous fashion designer.

Compared to Lan, who also designed cue cards for students, Hoa's speaking prompts were illustrative. However, this technique left room for students' freedom of expression, as it did not specify what kinds of jobs or ideas they should mention. This is a crucial part of CLT (Nunan, 1987; Tan, 2005), thus also targeted to the development of DC, particularly in terms of cohesion and coherence.

To reject pre-existing stereotypes about the teacher requiring students' confirmation and respect as a superior (Nguyen, 2002), Hoa spent a significant amount of time listening to each student's idea like a close friend. She emphasised establishing the link between the content of the speech and students' personal experience "because that is what stays with the audience after the talk". By pointing students to the fact that their presentations need to leave an impact on the audience, Hoa could raise their awareness of the features of the context where the genre was used (Flowerdew, 2002).

\section{[Observation extract 6]}

Hoa: So when you are doing a presentation, the point is you are not only giving them the information, but you need to change their perceptions. Let's say, if you talk about one famous sports player, this should be easy, right? Like okay, I will talk about Quang Hai, and I will talk about his achievements, blah blah.. That is not particularly interesting. But if you could tell your personal story about what Quang Hai means to you, it's a much better hook. You can offer the audience another dimension to look at Quang Hai.

Apart from this, she carefully designed the marking rubric for the assignment and asked students to read them aloud and asked for their feedback. This could set the goal clear to motivate students to participate (William, 2013) and promote task authenticity (Willis, 1996).

\section{Lien - The constructor}

Lien was the EFL teacher with the most extended years of practice compared to the other cases. She was also the only teacher with experience as a manager and head of the English as a second language academic department in her previous high school. Lien mainly taught advanced levels and adhered to the constructivism teaching model. She was viewed as a conductor because she allowed great learners' autonomy in class and only offered sufficient facilitation when necessary.

She helped students develop coherence by stimulating students to revise their speech and refer it to the contexts, the key to communication (Savignon, 1983). To do this, Lien did not limit her feedback on the arguments that students proposed in class but extended it by asking follow-up questions. This propelled students to refer to their previous parts of the speech and point towards their subsequent propositions. As a result, constant practice of extended argumentative activities gave students chances of mastering the uses of references, discoursal deixis, and thematic staging (Hanks, 1992, p. 47; Dörnyei \& Thurrell, 1994). 


\section{[Observation extract 7]}

(One group of students was presenting about the uses of emoji in online communication)

Student A (presenter): Sometimes emoji is also used for dark humour, a sarcastic way to make a joke but not offensive.

Student B (audience): Can dark humour be a milder form of cyberbullying?

Student A: No, it's just for fun, not for criticism, and people do not take it seriously.

Lien: To some people, they might take the joke lightly, but others might take it seriously, and the joke can actually offend or hurt them. A, do you have any opinion on this?

Student A: I believe emoji is used positively and rarely for cyber bullying.

Because Lien's class was of advanced level, the input Lien prepared for them was far more diversified. For example, she started to introduce to them the idioms based on different themes or topics. In one lesson, she asked the class for revision of the previously taught idiomatic expressions. Surprisingly, the class could remember all of them and use them in the speaking practice activities. Since when the nature of second language acquisition is not a habit formation (Piaget, 1976) but rather be a cognitive process (Hammerly, 1975; Fischer, 1979), creating opportunities for students to interact with the target content was a rational way to reap the content from the input for coherence and cohesion consolidation.

[Interview extract 4]

When I want to introduce a new vocab or idiom, I tend to use prompts, like pictures. In class today, I show them a picture of a baby monkey holding a rope. So I ask them: "What do you see? A baby monkey. Why is the monkey holding the rope? Because the rope might help the monkey climb the tree. So, you have the idea. Anyone who is new in the company has to learn their ways like the monkey". Some teachers might be like, "Here is what we learn today." But I always want them to interact with the content. They will truly remember it and feel motivated to use it for their own good. (Lien)

On the condition that Lien's students had mastered the rhetorical structures of the genre, Lien adopted a flipped model to save students' time. She guided them to research the topic at home then engaged in multiple activities in class (Rajesh, 2015). This gave students plenty of space to find out for themselves how to form the discourse that was intact, coherent, and persuasive to the listeners (Rajesh, 2015).

\section{[Observation extract 8]}

(A group has just done presenting about high-end fashion brand using animals as one of the materials for their products)

Lien: Now, there are many organisations which are fighting against excessive animal killing for fashion and therefore fighting for animal rights, like PETA. Now, my question is: Why can't we close companies that are excessively killing animals?

Students A: From my point of view, because they are very strong companies that have a huge impact on the economy worldwide. If we remove them there will be a lot of relevant issues. So it's not easy to shut them down.

Lien: That's right. And one of the issues that these companies cannot be closed down easily is that they are providing jobs for a lot of people. There are people who are depending on them for, basically, their dayto-day incomes.

Student B: And because they provide a lot of taxes for the society too. 
Lien: That is an interesting idea. Do you want to talk more about that, B?

(The discussion continued for a while)

The arguments in the Q\&A session after each presentation were appropriately supported thanks to the preparation in advance. Lien periodically announced the presentation assignment as a small project, so students had to put more time and effort into upgrading their final product. This project-based learning model required deeper cognitive functions (Bransford et al., 1999), which laid the groundwork for discourse construction $(\mathrm{Li}, 2013)$.

\section{Less covered areas}

The data showed that two aspects of DC were much less mentioned, including deixis and conversational structures. The exclusive teaching of deixis was meagre, while deixis was "the key points of juncture between grammar and context" (Hanks, 1992, p. 47). On the condition that the desirable outcomes of CLT are the competencies to communicate appropriately in contexts (Savignon, 1983), deictic expressions should be the field within the spotlight. Similarly, conversational structures, the backbone that keeps the conversation going without breaking down (Dörnyei et al., 1994), deserved to be noticed more. However, the four teachers had admitted that they presumed the students would naturally obtain the rules of conversation and deixis through the communicative activities they attended in class. This presumption might be true, as indirect teaching of grammatical and linguistics regulations is integral to CLT (Richards, 1990). Notwithstanding, more direct instructions to raise students' consciousness over these matters were necessary because such methods rendered the faster and more deliberated understanding of the subject (Rutherford \& Smith, 1985; Widdowson, 2001; Richards, 1990).

\section{Conclusion}

Regardless of the limitations coming from the study's scope and other practical issues, the findings of this study call into attention a few notable phenomena that might carry meaningful implications. EFL teachers were standing in a dilemma between the new teaching agenda and the remnant of old language teaching practices. To help students overcome affective barriers and the negative impacts of traditional teaching methods, teachers had to be versatile to adapt to different types of learners. Despite having distinct teaching styles, the four investigated cases shared common ground in their practices to cultivate DC in students. These practices, therefore, had been confirmed by previous studies, which were: 1) following an inputto-output sequencing and putting effort in introducing a wide range of input; 2) providing proper scaffoldings, particularly task repetition and pre-task planning; 3) giving priority to help students to overcome their affective barriers before DC development; 4) providing chances of putting forward authentic ideas and participating in meaning negotiations and 5) preparing a well-defined marking rubric and training students carefully to make peerfeedback more effective. These implications could be meaningful for three aspects. First, the MOET is currently gathering force to improve the professional standards of EFL teachers to standardise English teaching according to Decision 2080 (MOET, 2017). As a result, the data from this study can enrich the input for teachers' training programs, especially concerning the principles they should consider during practices. Another central idea was that the incorporation of various inputs was deemed to be pivotal. Therefore, both the teachers and material designers should be more aware of establishing an input database for EFL learners. 


\section{References}

Bachman, L. F. (1990). Fundamental considerations in language testing. Oxford University Press.

Belmonte, I. A., \& McCabe, A. (2004). The development of written discourse competence in ELT materials: A preliminary analysis. Revista Canaria de Estudios Ingleses, 49, 29-48.

Berg, E. C. (1999). The effects of trained peer response on ESL students' revision types and writing quality. Journal of Second Language Writing, 8(3), 215-241.

Borg, S. (2006). The distinctive characteristics of foreign language teachers. Language Teaching Research, 10(1), 3-31.

Bransford, J. D., Brown, A. L., \& Cocking, R. R. (1999). How people learn: Brain, mind, experience, and school. National Academies Press.

Braun, V., \& Clarke, V. (2006). Using thematic analysis in psychology. Qualitative Research in Psychology, 3(2), 77-101.

Brown, H. D. (2000). Principles of language learning and teaching (Vol. 4). Longman.

Bui, T. M. H. (2006). Teaching speaking skills at a Vietnamese university and recommendations for using CMC. Asian EFL Journal, 14, Article 2.

Cameron, L., Moon, J., \& Bygate, M. (1996). Language development of bilingual pupils in the mainstream: How do pupils and teachers use language? Language and Education, 10(4), 221-236.

Canale, M. (1983). From communicative competence to communicative language pedagogy. Language and Communication, 1(1), 1-47.

Canale, M., \& Swain, M. (1980). Theoretical bases of communicative approaches to second language teaching and testing. Applied Linguistics, 1(1), 1-47.

Carroll, K., Iedema, R., \& Kerridge, R. (2008). Reshaping ICU ward round practices using video-reflexive ethnography. Qualitative Health Research, 18(3), 380-390.

Castro, P., Sercu, L., \& Méndez García, M. D. C. (2004). Integrating language-and-culture teaching: An investigation of Spanish teachers' perceptions of the objectives of foreign language education. Intercultural Education, 15(1), 91-104.

Celce-Murcia, M. (2008). Rethinking the role of communicative competence in language teaching. In E. Alcón Soler \& M. P. Safont Jordà (Eds.), Intercultural language use and language learning (pp. 41-57). Springer.

Celce-Murcia, M., Dörnyei, Z., \& Thurrell, S. (1995). Communicative competence: A pedagogically motivated model with content specifications. Issues in Applied linguistics, 6(2), 5-35.

Chaudron, C. (1988). Second language classrooms: Research on teaching and learning. Cambridge University Press.

Chomsky, N. (2014). Aspects of the theory of syntax (Vol. 11). MIT Press.

Chun, D. M. (1994). Using computer networking to facilitate the acquisition of interactive competence. System, 22(1), 17-31.

Cohen, Y., \& Norst, M. J. (1989). Fear, dependence and loss of self-esteem: Affective barriers in second language learning among adults. RELC Journal, 20(2), 61-77.

Collier, A., Phillips, J. L., \& Iedema, R. (2015). The meaning of home at the end of life: A videoreflexive ethnography study. Palliative Medicine, 29(8), 695-702.

Cziko, G. A. (1978). Differences in first-and secondlanguage reading: The use of syntactic, semantic and discourse constraints. Canadian Modern Language Review, 34(3), 473-489.

Do, B. Q. (2009). Vai trò của kiến thức đầu vào trong phát triển năng lực giao tiếp ngoại ngữ [The role of input knowledge in the developing of foreign language communicative competence]. VNU Journal of Foreign Studies, 25(3), 140-145.

Do, T. X. D. (2018). Những ứng dụng của nghiên cứu diê̂n ngôn vào giảng dạy ngôn ngữ [Practical applications of discourse study on language teaching]. Hue University Journal of Science: Social Sciences and Humanities, 127(6A), 55-67.

Do, T. X. D., \& Truong, T. C. (2018). Discourse structure and its implication in the reading classes. Hue University Journal of Science: Social Sciences and Humanities, 127(6B), 39-46.

Dönyei, Z. (2007). Research methods in applied linguistics. Oxford University Press.

Dörnyei, Z., \& Thurrell, S. (1994). Teaching conversational skills intensively: Course content and rationale. ELT Journal, 48, 40-49. 
Edwards, A. D. (1987). Language code and classroom practice. Oxford Review of Education, 13(3), 237-247.

Egan, K. B. (1999). Speaking: A critical skill and a challenge. CALICO Journal, 16(3), 277-293.

Ellis, E. (2002). Teaching from experience: A new perspective on the non-native teacher in adult ESL. Australian Review of Applied Linguistics, 25(1), 71-107.

Ellis, N. C. (2008). The dynamics of second language emergence: Cycles of language use, language change, and language acquisition. The Modern Language Journal, 92(2), 232-249.

Feagin, J. R., Orum, A. M., \& Sjoberg, G. (Eds.). (1991). A case for the case study. UNC Press Books.

Fischer, R. A. (1979). The inductive-deductive controversy revisited. The Modern Language Journal, 63(3), 98-105.

Flowerdew, J. (2002). Genre in the classroom: A linguistic approach. In A. M. Johns (Ed.), Genre in the classroom: Multiple perspectives (pp. 91-102). Routledge.

Gable, G. G. (1994). Integrating case study and survey research methods: An example in information systems. European Journal of Information Systems, 3(2), 112-126.

Golkova, D., \& Hubackova, S. (2014). Productive skills in second language learning. Procedia-Social and Behavioral Sciences, 143, 477-481.

Grossman, P., Compton, C., Igra, D., Ronfeldt, M., Shahan, E., \& Williamson, P. (2009). Teaching practice: A cross-professional perspective. Teachers College Record, 111(9), 2055-2100.

Halliday, M., \& Hasan, R. (1989). Language, context, and text: Aspects of language in a social semiotic perspective. Oxford University Press.

Hammerly, H. (1975). The deduction/induction controversy. The Modern Language Journal, 59(1/2), 15-18.

Hanks, W. F. (1992). The indexical ground of deictic reference. Cambridge University Press.

Hussein, N. O., \& Elttayef, A. I. (2016). The impact of utilising Skype as a social tool network community on developing English major students' discourse competence in the English language syllables. Journal of Education and Practice, 7(11), 29-33.
Hymes. D. (1972). On communicative competence. In J. Pride \& J. Holmes (Eds.), Sociolinguistics (pp. 269-293). Penguin Books.

Kinneavy, J. L. (1971). A theory of discourse. W.W. Norton \& Company.

Lampert, M. (2010). Learning teaching in, from, and for practice: What do we mean? Journal of Teacher Education, 61(1-2), 21-34.

Larrivee, B. (2008). Development of a tool to assess teachers' level of reflective practice. Reflective Practice, 9(3), 341-360.

Le, N. (2011, May 21). Vì sao học sinh Việt Nam "ngại" nói tiếng Anh? [Why do Vietnamese students hesitate to speak English?]. Dân trí. https://dantri.com.vn/giao-duc-huongnghiep/vi-sao-hoc-sinh-viet-nam-ngai-noitieng-anh-1306225111.htm

Legutke, M. K. (2012). Teaching teenagers. In J. C. Richards \& A. Burns (Eds.), The Cambridge guide to pedagogy and practice in second language teaching. Cambridge University Press.

Li, D. (1998). It's always more difficult than you plan and imagine: Teachers' perceived difficulties in introducing the communicative approach in South Korea. TESOL Quarterly, 32, 677-703.

Li, H., \& Lui, Y. (2011). A brief study of reticence in ESL class. Theory and Practice in Language Studies, 1(8), 961-965.

Li, J. (2013). The application and significance of discourse cohesion and analysis in practical teaching of foreign language. Theory and Practice in Language Studies, 3(8), 1393.

Liao, X. (2000). How communicative language teaching became acceptable in secondary schools in China. The Internet TESL Journal, 6(10). http://iteslj.org/Articles/LiaoCLTinChina.html

Long, M. H. (1981). Input, interaction, and secondlanguage acquisition. Annals of the New York Academy of Sciences, 379(1), 259-278.

MacIntyre, P. D., \& Gardner, R. C. (1989). Anxiety and second-language learning: Toward a theoretical clarification. Language Learning, 39(2), 251-275.

Maley, A. (1984). On chalk and cheese, babies and bathwater and squared circles: Can traditional and communicative approaches be reconciled? In P. Larson, E. L. Judd \& D. S. Messerschmitt (Eds.), On TESOL'84 (pp. 159-169). TESOL. 
Mauranen, A. (1996). Discourse competence evidence from thematic development in native and non-native texts. In E. Vantola \& A. Mauranen (Eds.), Pragmatics and beyond new series (pp. 195 -230). John Benjamins Publishing Company.

McCarthy, M. (1991). Discourse analysis for language teachers. Cambridge University Press.

Merrell, J., \& Williams, A. (1994). Participant observation and informed consent: Relationships and tactical decision-making in nursing research. Nursing Ethics, 1(3), 163-172.

National Center for Education. (2019, July 24). Giáo viên, yếu tố then chốt nâng cao chất lượng dạy và học ngoại ngữ [Teachers as the key factor in enhancing foreign language education's quality]. Vietnam Ministry of Education and Training. https://moet.gov.vn/Pages/timkiem.aspx?ItemID=6131

Ngo, H. H. (2012). Vai trò của văn hóa và kiến thức văn hóa nền trong việc hình thành và tiếp nhận diễn ngôn [The role of culture and cultural knowledge in discourse formation and acquisition]. VNU Journal of Foreign Studies, 28(1), 25-32.

Ngoc, D. (2021, April 14). Các trường xét tuyển bằng chứng chỉ quốc tế, nhiều học sinh thiệt thòi? [English international certificate as an significant advantage in higher education's application: An opportunity or barrier?] Tuổi trẻ online. https://tuoitre.vn/cactruong-xet-tuyen-bang-chung-chi-quoc-tenhieu-hoc-sinh-thiet-thoi20210414084953175.htm

Nguyen, H. N. (2021, March 12). 'Tôi biết nhiều học sinh học chưa tốt tiếng Anh' [I am aware that there are students who might not be fluent in English]. Tuổi trẻ online. https://tuoitre.vn/toi-biet-nhieu-hoc-sinhhoc-chua-tot-tieng-anh20210312215855479.htm

Nguyen, Q. (2016). Từ năng lực ngôn ngữ đến năng lực liên văn hoá [From linguistic competence to intercultural competence]. VNU Journal of Foreign Studies, 32(3), 1-9.

Nguyen, Q. T., Duong, C. D., \& Vu, K. H. (2017). Thiết kế chương trình bổ trợ nói cho học sinh lớp 10 trường trung học phổ thông Thái Nguyên [Designing a supplementary English speaking material for the $10^{\text {th }}$ form students at Thai Nguyen high school]. Tap chí Khoa họ và Công nghệ - Đại học Thái Nguyên, 167(07), 67-71.

Nguyen, T. H. (2002). Vietnam: Cultural background for ESL/EFL teachers. The Review of Vietnamese Studies, 2(1), 1-6.

Nguyen, T. T. H., \& Nguyen, T. H. (2020). Nghiên cứu sử dụng tài liệu bổ trợ trong dạy kỹ năng nói tiếng Anh tại trường trung học phổ thông [An investigation into using supplementary materials in teaching English speaking skills at high school]. TNU Journal of Science and Technology, 225(12), 64-69.

Ntuli, D., \& Pretorius, E. J. (2005). Laying foundations for academic language competence: The effects of storybook reading on Zulu language, literacy and discourse development. Southern African Linguistics and Applied Language Studies, 23(1), 91-109.

Nunan, D. (1987). Communicative language teaching: Making it work. ELT Journal, 41(2), 136-145.

Pace, G. (1992). Stories of teacher-initiated change from traditional to whole-language literacy instruction. Elementary School Journal, 92(4), 461-476.

Pennycook, A. (1994). Incommensurable discourses? Applied Linguistics, 15(2), 115-138.

Pham, H. H. (2007). Communicative language teaching: Unity within diversity. ELT Journal, 61(3), 193-201.

Pham, H. L. (2017). Phát triển năng lực tiếng của người học dưới ánh sáng lý luận ngôn ngữ học hiện đại [Language learners' proficiency development in the light of modern linguistics]. Tạp chí Khoa học giáo dục, 142, 34-37.

Piaget, J. (1976). Piaget's theory. In B. Inhelder, N. N. Chipman \& C. Zwingmann (Eds.), Piaget and his school (pp. 11-23). Springer.

Postiglione, G. A., Wang, L. \& Watkins, D. (2008). Vocational and continuing education in China. In P. A. Elsner, G. R. Boggs \& J. T. Irwin (Eds.), Global development of community colleges, technical colleges, and further education programs (pp. 91-104). American Association of Community Colleges.

Rajesh, M. (2015). Revolution in communication technologies: Impact on distance education. Turkish Online Journal of Distance Education, 16(1), 62-88. 
Richard, J. C. (1990). Conversationally speaking: Approaches to the teaching of conversation. In J. C. Richards (Ed.), The language teaching matrix: Curriculum, methodology, and material (pp. 67-86). Cambridge University Press.

Richards, J. C. (2005). Communicative language teaching today. SEAMEO Regional Language Centre.

Rutherford, W. E., \& Smith, M. S. (1985). Consciousness-raising and universal grammar. Applied Linguistics, 6(3), 274-282.

Saldaña, J. (2009). The coding manual for qualitative researchers. Sage Publications Ltd.

Savaşçı, M. (2014). Why are some students reluctant to use L2 in EFL speaking classes? An action research at tertiary level. ProcediaSocial and Behavioral Sciences, 116, 26822686.

Savignon, S (1983). Communicative competence: Theory and classroom practice. AddisonWesley.

Segalowitz, N. (2010). Cognitive bases of second language fluency. Routledge.

Skehan, P. (1998). A cognitive approach to language learning. Oxford University Press.

Stern, H. H., Tarone, E. E., Stern, H. H., Yule, G., \& Stern, H. (1983). Fundamental concepts of language teaching: Historical and interdisciplinary perspectives on applied linguistic research. Oxford University Press.

Tan, M. (2005). CLT - beliefs and practices. Journal of Language and Learning, 3(1), 104-115.

Vietnam Ministry of Education and Training (2017). Quyết định số 2080/QĐ-TTg về phê duyệt điều chỉnh, bổ sung Đề án dạy và học ngoại ngữ trong hệ thống giáo dục quốc dân giai đoạn 2017-2025 [Decision No. 2080/QĐTTg on the approval of adjustments and additions to the project entitled "Teaching and learning foreign languages in the national education system, period 20172025"].

Vietnam Ministry of Education and Training (2018). Thông tư số 32/2018/TT-BGDĐT về ban hành chương trình giáo dục phổ thông: Chương trình môn Tiếng Anh [Circular No. 32/2016 QĐ-TTg on the publication of general education program: English as a foreign language program].

Vygotsky, L. (1978). Interaction between learning and development. Readings on the Development of Children, 23(3), 34-41.

Widdowson, G. H. (2001). Aspects of language teaching. Oxford University Press.

Wiggins, G., \& McTighe, J. (2006). Examining the teaching life. Educational Leadership, 63(6), 26-29.

Wiliam, D. (2013). Assessment: The bridge between teaching and learning. Voices from the Middle, 21(2), 15.

Willis, J. (1996). A framework for task-based learning (Vol. 60). Longman.

Wood, D., Bruner, J. S., \& Ross, G. (1976). The role of tutoring in problem solving. Journal of Child Psychology and Psychiatry, 17(2), 89-100.

Yang, W., \& Sun, Y. (2012). The use of cohesive devices in argumentative writing by Chinese EFL learners at different proficiency levels. Linguistics and Education, 23(1), 31-48.

Zhu, W. (1995). Effects of training for peer response on students' comments and interaction. Written Communication, 12(4), 492-528. 


\title{
THỰC HÀNH CỦA GIÁO VIÊN TIẾNG ANH TRONG VIỆC PHÁT TRIỂN NĂNG LỰC DIỄN NGÔN THÔNG QUA KỸ NĂNG NÓI CHO HỌ̣C SINH LỚP 10: NGHIÊN CÚUU TRƯỜNG HỢP ĐIẾN HİNH
}

\author{
Vũ Hải Hà, Nguyễn Nhã Uyên \\ Khoa Su phạm tiếng Anh, Truờng Đại học Ngoại ngũu, Đại học Quốc gia Hà Nội, \\ Phạm Văn Đồng, Cầu Giány, Hà Nội, Việt Nam
}

Tóm tắt: Tiếng Anh hiện nay đã trở thành môn học bắt buộc từ bậc tiểu học và dần trở thành một tiêu chí xét tuyển quan trọng tại các bậc đại học và cao đẳng, cho nên việc học tiếng Anh đã trở thành ưu tiên hàng đầu của rất nhiều học sinh trung học phổ thông (Nguyen, 2021). Thêm vào đó, việc học tiếng Anh hiện nay đang hướng đến hình thành năng lực giao tiếp cho học sinh, mà năng lực diễn ngôn chính là một phần không thể thiếu. Đây cũng là một mục tiêu then chốt được khẳng định trong Thông tư 32 (2018) của Bộ Giáo dục và Đào tạo. Mặc dù chương trình tiếng Anh mới đã có sự chú trọng nhiều hơn vào các kĩ năng giao tiếp như nghe và nói, nhưng học sinh vẫn gặp nhiều khó khăn khi diễn ngôn bằng lời (Le, 2011). Để mở ra những phương án giải quyết nhằm nâng cao năng lực diễn ngôn thông qua kĩ năng nói cho học sinh, nghiên cứu đã tập trung vào bốn đối tượng giáo viên tiếng Anh với lý lịch, kinh nghiệm và phong cách giảng dạy đa dạng từ một hệ thống giáo dục đã hai lần được giải thưởng của Bộ Giáo dục và Đào tạo cho những đóng góp vào phong trào cải cách giáo dục và đưa đường hướng giao tiếp vào giảng dạy tiếng Anh. Sau khi thực hiện phỏng vấn và quan sát lớp học của bốn giáo viên, nghiên cứu nhận thấy giáo viên thường kết hợp linh hoạt nhiều cách tiếp cận khác nhau để giúp học sinh phát triển năng lực diễn ngôn, tuy nhiên, sự kết hợp này vẫn phản ảnh đúng phương châm và phong cách giảng dạy của giáo viên đó. Kết quả của nghiên cứu có thể trở thành nguồn tham khảo hữu ích cho các giáo viên tiếng Anh, cũng như mở ra bước đầu trong việc xây dựng một bộ quy chiếu giúp giáo viên tự tìm ra phương pháp thích hợp để nâng cao năng lực diễn ngôn cho học sinh của mình.

Tù̀ khóa: giáo viên tiếng Anh, năng lực diễn ngôn, kĩ năng nói, nhận thức, thực hành, học sinh lớp 10, Hà Nội 